\title{
Corporate Sustainability Planning Tools for Knowledge-Intensive Enterprises
}

\author{
Alexander Tsvettsykh \\ Engineering and Economics Institute \\ Reshetnev Siberian State University of Science and \\ Technology \\ Krasnoyarsk, Russia \\ tsvettsykhalex@mail.ru
}

\author{
Natalia Shevtsova \\ Engineering and Economics Institute \\ Reshetnev Siberian State University of Science and \\ Technology \\ Krasnoyarsk, Russia \\ Ribachek78@mail.ru
}

\author{
Tatiana Afanasyeva \\ Engineering and Economics Institute \\ Reshetnev Siberian State University of Science and Technology \\ Krasnoyarsk, Russia \\ afanaseva701@yandex.ru
}

\begin{abstract}
Currently, there is a need to reform the Russian rocket and space complex (RSC) in order to strengthen its role in ensuring the scientific and technological development of the Russian economy. Reorientation of scientific, technical and personnel potential enterprises for the needs of the market is associated with changes in the conditions of RSC functioning and development. Diversification of RSC production for the civilian products becomes the most important tasks in the development of RSC enterprises. The successful solution of this problem is possible only with integration of personnel, scientific, technical and financial potentials for the production of competitive engineering products. In these conditions, the problem of ensuring sustainable development of RSC enterprises on the basis of the development and using special corporate governance systems of RSC enterprises becomes particularly urgent.

The proposed tools for corporate financial planning of RSC enterprises were the results of the research.
\end{abstract}

Keywords: sustainable development of knowledge-intensive enterprises, rocket and space industry, corporate planning tools, human resources, scientific and technical potential

\section{INTRODUCTION}

The aim of the study was the formation of theoretical and methodological foundations in the tools development for corporate planning of sustainable development for high-tech enterprises (on the example of enterprises at the rocket and space industry). The generalizing feature of sustainable development in a knowledge-intensive enterprise is its financial stability, which largely depends on the correctness of the chosen technological strategy. The choice of planning tools is justified by the system of factors and the methodological basis for planning the development of a knowledge-intensive enterprise. In this regard, at the first stage it is necessary to study and generalize the factors of financial stability that require consideration at the level of planning sustainable development of a knowledge-intensive enterprise. At the second stage of planning tools justification it is necessary to form a methodological basis for planning sustainable development. To solve this problem, it is necessary to identify the development laws of high-tech enterprises and substantiate the methodological principles of planning.

\section{METHODS AND RESULTS}

The methods of system and factor analysis, expert evaluation methods were used to solve the tasks of the study. The identifying factors of enterprises financial stability for rocket-space industry (RSI) were conducted on the basis of static material and conceptual documents study for the development of rocket-space industry of Russia and other countries. Confirmation of the findings and results carried out on the basis of practical propositions and recommendations presented in the modern Russian and foreign literature on the enterprises development problems of space-rocket industry. As a result, the identification model of technological strategy for the high-tech enterprises allowing justifying architecture of the projected integrated structure was offered.

\section{DISCUSSION}

As a result of the RSI current economic environment and development, the authors have refined the essence of financial stability in RSI enterprises on the basis of the main symptom sustainability categories - the system ability to return to a 
TABLE I. FACTORS CLASSIFICATION OF FINANCIAL STABILITY FOR THE INTEGRATED STRUCTURE enterprise refers to its ability to maintain a state of balance, proportionality and efficiency of operation financial and economic processes, which creates the preconditions for the development of the enterprise.

The theoretical basis for the selection and classification of financial stability factors in the RSI enterprise were the works of Russian [1-11] and foreign experts [12-20], devoted to various problems study of sustainable development in hightech enterprises. The factors classification list of financial stability was not chosen by chance, their list is subordinate to the goal of the research is to develop theoretical and methodological foundations and corporate planning tools for sustainable development of the RSI enterprise. Taking into account the possibility of regulation to justify the forms and options for the integration of enterprises required the factors separation of financial stability into regulated and poorly regulated with the decomposition of the functional areas for planning a knowledge-intensive enterprise: sales and service, research and development, production, financing. For the purposes of selecting corporate planning tools, it is necessary to separate the factors of financial stability by the nature of the input information.

\section{CONCLUSIONS}

Financial stability factors of RSI high-tech enterprises on the selected features of the classification and their expert assessment (on a scale of 1 to 3 points) is given in table I. The classification and expert evaluation of factors carried out by the authors made it possible to identify a list of factors to be taken into account at the strategic planning level.

\begin{tabular}{|c|c|c|c|}
\hline \multicolumn{2}{|r|}{$\begin{array}{c}\text { Factors on functional areas of } \\
\text { planning }\end{array}$} & $\begin{array}{c}\text { Expert } \\
\text { assessment } \\
\text { of the } \\
\text { factor }\end{array}$ & $\begin{array}{l}\text { Nature of } \\
\text { information }\end{array}$ \\
\hline \multirow{15}{*}{ 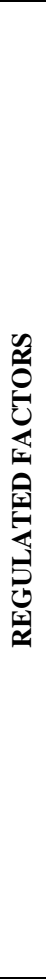 } & \multicolumn{3}{|c|}{ Sales and service } \\
\hline & $\begin{array}{l}\text { Diversification of markets and } \\
\text { products (services) }\end{array}$ & 3 & $\mathrm{P} / \mathrm{D}$ \\
\hline & $\begin{array}{l}\text { Control technologies of products } \\
\text { technical condition in the course } \\
\text { of their operation }\end{array}$ & 1 & $\mathrm{P} / \mathrm{D}$ \\
\hline & \multicolumn{3}{|c|}{ Research and development work } \\
\hline & $\begin{array}{l}\text { Moral and physical deterioration } \\
\text { of the ground test base }\end{array}$ & 2 & $\mathrm{D}$ \\
\hline & $\begin{array}{l}\text { Terms of development, tactical } \\
\text { and technical characteristics of } \\
\text { the created scientific and } \\
\text { technical reserves and test } \\
\text { samples }\end{array}$ & 3 & $\mathrm{P} / \mathrm{D}$ \\
\hline & $\begin{array}{l}\text { Quality, reliability and cost of } \\
\text { projected samples }\end{array}$ & 2 & $\mathrm{P} / \mathrm{D}$ \\
\hline & \multicolumn{3}{|l|}{ Production } \\
\hline & $\begin{array}{l}\text { Moral and physical depreciation } \\
\text { of fixed assets }\end{array}$ & 2 & $\mathrm{D}$ \\
\hline & $\begin{array}{l}\text { Progressiveness of production } \\
\text { technologies and product quality } \\
\text { control }\end{array}$ & 2 & $\mathrm{P} / \mathrm{D}$ \\
\hline & $\begin{array}{l}\text { Qualification, motivation and } \\
\text { discipline of staff }\end{array}$ & 2 & $\mathrm{D}$ \\
\hline & $\begin{array}{l}\text { Competitiveness of products and } \\
\text { services }\end{array}$ & 2 & $\mathrm{P} / \mathrm{D}$ \\
\hline & \multicolumn{3}{|c|}{ Financing and investments } \\
\hline & $\begin{array}{l}\text { Share of civil projects in the } \\
\text { structure of financial results }\end{array}$ & 2 & $\mathrm{D}$ \\
\hline & Profitability of production & 3 & $\mathrm{D}$ \\
\hline \multirow{14}{*}{ 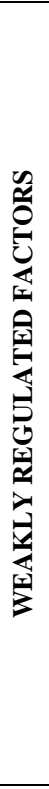 } & \multicolumn{3}{|c|}{ Sales and service } \\
\hline & $\begin{array}{l}\text { The level of competition in the } \\
\text { world market of products and } \\
\text { services }\end{array}$ & 2 & $\mathrm{P} / \mathrm{D}$ \\
\hline & State support in foreign markets & 2 & $\mathrm{D}$ \\
\hline & \multicolumn{3}{|c|}{ Research and development work } \\
\hline & $\begin{array}{l}\text { Level of international scientific } \\
\text { and technical cooperation }\end{array}$ & 1 & $\mathrm{P} / \mathrm{D}$ \\
\hline & $\begin{array}{l}\text { State scientific and technical } \\
\text { policy }\end{array}$ & 2 & $\mathrm{P} / \mathrm{D}$ \\
\hline & \multicolumn{3}{|c|}{ Production } \\
\hline & $\begin{array}{l}\text { The discipline of compliance by } \\
\text { contractors }\end{array}$ & 2 & $\mathrm{P} / \mathrm{D}$ \\
\hline & $\begin{array}{l}\text { Level of international production } \\
\text { cooperation }\end{array}$ & 1 & $\mathrm{P} / \mathrm{D}$ \\
\hline & $\begin{array}{l}\text { State policy in the field of } \\
\text { industrial development }\end{array}$ & 2 & $\mathrm{P} / \mathrm{D}$ \\
\hline & \multicolumn{3}{|c|}{ Financing and investments } \\
\hline & $\begin{array}{l}\text { Quality of control over the use } \\
\text { of targeted state funding }\end{array}$ & 2 & $\mathrm{P} / \mathrm{D}$ \\
\hline & $\begin{array}{l}\text { Efficiency of the state pricing } \\
\text { model for special products }\end{array}$ & 2 & P/D-D \\
\hline & $\begin{array}{l}\text { Diversity and availability of } \\
\text { investment funds, cost of funds }\end{array}$ & 3 & P/D-D \\
\hline
\end{tabular}

The choice of tools for planning sustainable development of RSI enterprises requires justification and consideration of special methodological principles.

Taking into account the modern goals and features of the RSI development allows us to identify patterns of RSI 
Growth potential of a business unit corporate planning principles.

The statistical studies results of RSI development status and trends and allocated patterns: negentropic character development system as a supply result from outside of the intelligence and resources; increasing the value of the underlying innovations under the influence of worsening economic security threats of the states; the increase in the number of alternatives to «business combinations» by a preponderance of the innovation factor in the development; reducing the life cycles duration of innovation; increase the resilience of economic systems as a result of increased uncertainty in innovation effectiveness. Further, in accordance with the identified patterns of RSI development, the corresponding principles of corporate planning for knowledgeintensive enterprises were substantiated.

Decomposition of planning principles by decision-making level allowed taking into account the difference in strategic decision-making (corporation level, business unity level). Further, the authors propose a decomposition of planning principles in accordance with the selected patterns of sustainable development (table II).

TABLE II. PRINCIPLES OF PLANNING SUSTAINABLE DEVELOPMENT OF ROCKET AND SPACE INDUSTRY ENERPRISES

\begin{tabular}{|c|c|c|}
\hline \multirow{2}{*}{$\begin{array}{c}\text { Regularities of RSI } \\
\text { sustainable } \\
\text { development }\end{array}$} & \multicolumn{2}{|c|}{$\begin{array}{l}\text { The composition of the planning principles } \\
\text { with planning levels }\end{array}$} \\
\hline & Corporate level & $\begin{array}{c}\text { The level of business } \\
\text { units }\end{array}$ \\
\hline $\begin{array}{l}\text { Negentropic character of } \\
\text { development system as a } \\
\text { result of supply from } \\
\text { outside of } r \text { the } \\
\text { intelligence } \\
\text { resources }\end{array}$ & $\begin{array}{l}\text { Adaptability, } \\
\text { efficiency, flexibility, } \\
\text { continuity, optimality }\end{array}$ & $\begin{array}{l}\text { Accuracy, relevance, } \\
\text { alternativeness, } \\
\text { continuity, } \\
\text { adaptability }\end{array}$ \\
\hline $\begin{array}{l}\text { Increasing the } \\
\text { importance of basic } \\
\text { innovations under the } \\
\text { intensification influence } \\
\text { of threats to the } \\
\text { economic security of the } \\
\text { state }\end{array}$ & $\begin{array}{l}\text { Alternativeness, } \\
\text { flexibility, hierarchy, } \\
\text { optimality }\end{array}$ & $\begin{array}{l}\text { Accuracy, relevance, } \\
\text { alternativeness, } \\
\text { optimality }\end{array}$ \\
\hline $\begin{array}{l}\text { The increase in the } \\
\text { number of alternatives } \\
\text { to «economic } \\
\text { combinations» as a } \\
\text { result of the } \\
\text { predominance of the } \\
\text { innovative factor in } \\
\text { development }\end{array}$ & $\begin{array}{l}\text { Alternativeness, } \\
\text { flexibility, } \\
\text { adaptability, } \\
\text { optimality }\end{array}$ & $\begin{array}{l}\text { Accuracy, relevance, } \\
\text { decomposability, } \\
\text { flexibility }\end{array}$ \\
\hline $\begin{array}{l}\text { Increase the resilience of } \\
\text { economic systems as a } \\
\text { result of increased } \\
\text { uncertainty in } \\
\text { innovation effectiveness }\end{array}$ & $\begin{array}{l}\text { Adaptability, } \\
\text { flexibility, criteria, } \\
\text { optimality }\end{array}$ & $\begin{array}{l}\text { Criteria, relevance, } \\
\text { accuracy }\end{array}$ \\
\hline
\end{tabular}

The original base model development corporate planning technology effectiveness - growth potential of the business unit was the study results of the concepts essence «sustainability», «development», «sustainable development», a study of corporate planning principles. The proposed model can be used in determining the potential business units of the corporate structure in the design of its architecture.

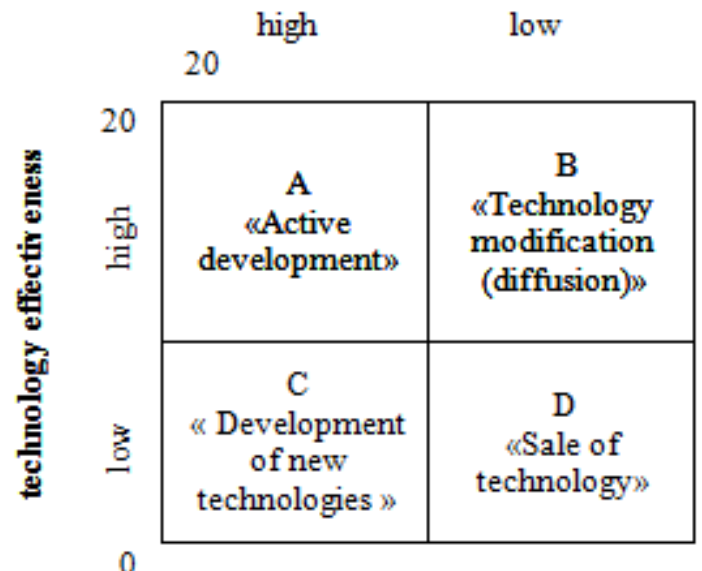

Fig. 1. The matrix «technology effectiveness - growth potential of a business unit» (A, B - technologies that have the highest effectiveness; 20 - the maximum value of the integral index; Intermediate values delimiting positions (matrix quadrants) are set by experts (can be equal to 10 points))

\section{REFERENCES}

[1] G. I. Latyshenko, D. D. Galchina, and M. A. Gubanova, "On the role of strategic planning of small enterprises in an unstable economic situation", Management of social and economic systems, 2017, vol. 16 (2), pp. 7-12.

[2] Yu. V. Erygin, L. V. Erygina, R. V. Votintsev, and F. P. Shumakov, "Reproduction of innovative potential as a result of rocket-space industry enterprises innovative activity", IOP Conf. Series: Materials Science and Engineering, 2019, vol. 537 [Electronic resource]. Available at: https://iopscience.iop.org/issue/1757-899X/537/4/.

[3] Z. E. Shaporova and A. V. Tsvettsykh, "Methodological foundations of the reference normalized model of an agricultural holding financial stability", IOP Conference Series: Earth and Environmental Science, vol. 315 [Electronic resource]. Available at: https://domnit.ru/images/Agri/1069.pdf.

[4] Yu. V. Erygin and A. V. Tsvetsykh, "Strategic planning tools for innovative development of defense enterprises", Krasnoyarsk: SibSAU, 2009, 172 p.

[5] A. V. Tsvettsykh, Y. V. Erygin, and S. V. Levchin, "Creative and innovative development of enterprises of the military-industrial complex of Russia: necessity and essence of the Management of social and economic systems", 2017, vol. 3, no 3 (7), pp. 34-44.

[6] V. Milovidov, "Innovation, Sustainable Growth, and Energy: Is Leap Forward for Civilization Possible? ", Foresight and STI Governance, 2019, vol. 13, no 1, pp. 62-68.

[7] R. Alferova, "The institutionalization of sustainable development of industrial enterprises", Herald of the University of Perm. Series "Economics", 2012, vol. 4, no. 15, pp. 28-33.

[8] A. A. Gibadullin, V. N. Pulyaeva, E. N. Kharitonova, Yu. V. Erygin, and N. A. Kharitonova, "Formation of a mechanism to ensure the stability of the electric power complex", IOP Conf. Series: Materials Science and Engineering 537, 2019 [Electronic resource]. Available at: https://iopscience.iop.org/issue/1757-899X/537/4.

[9] E. A. Tarkhanova, "Innovations and sustainability in the financial and banking sectors", Terra economicus, 2018, vol. 16, no. 2, pp. 75-82.

[10] N. M. Borisova, Y. V. Erygin, L. V. Erygina, V. B. Osipenko, and N. A. Shumakova, "Consideration of synergy in reforming the ICS RSI as a result of increasing high-tech civilian products", IOP Conf. Series: Materials Science and Engineering, 2019, vol. 537 [Electronic resource]. Available at: https://iopscience.iop.org/issue/1757-899X/537/4/. 
[16] S. Robert Kaplan and P. David Norton, "The Execution Premium: Linking Strategy to Operations for Competitive Advantage", Boston: Harvard Business School Press, 2008.

11] E. Rodionova and Zh. Kuzminykh, "Regional aspects of implementing innovations as a lever for economic growth and sustainable development in Russia", Proceedings of the International Scientific-Practical Conference "Business Cooperation as a Resource of Sustainable Economic Development and Investment Attraction", ISPCBC 2019 [Electronic resource]. Available at: https://www.atlantispress.com/proceedings/ispcbc-19/125914491.

[12] M. E. Porter and J. E. Heppelmann, "How Smart, Connected Products are Transforming Competition", Harvard Business Review, 2014, pp $65-88$.

[13] M. E. Porter and M. R. Kramer, "Creating Shared Value", Harvard Business Review, Jan/Feb 2011, Vol.

[14] M. E. Porter, "The Five Competitive Forces That Shape Strategy", Harvard Business Review January 2008, pp. 79-93.

[15] A. Atkinson, Anthony, S. Kaplan Robert, Ella Mae Matsumura, and S. Mark Young, "Management Accounting: Information for Decision Making and Strategy Execution", Pearson Education, 2011.

[17] E. Kembell and L. K. Sammerce, "Strategic synergism", SpB: Piter, 2014, 416 p.

[18] Sulieman Allawzi, "Rethinking Scenario Planning Potential Role in Strategy Making and Innovation: A Conceptual Framework Based on Examining Trends towards Scenarios and Firms Strategy", Academy of Strategic Management Journal, 2019, vol. 18, issue 5.

[19] S. Drobyazko, "Factors of influence on the sustainable development in the strategy management of corporations", Academy of Strategic Management Journal, 2019, vol. 18, special issue 1.

[20] A. Davila and M. M. Elvira, "Performance management in knowledge intensive enterprises: A case study", Universia Business Review 27: 124, 14 January 2010. 